\title{
PRP4: a Protein of the Yeast U4/U6 Small Nuclear Ribonucleoprotein Particle
}

\author{
JOSETTE BANROQUES AND JOHN N. ABELSON* \\ Division of Biology, California Institute of Technology, Pasadena, California 91125
}

Received 6 February 1989/Accepted 22 May 1989

\begin{abstract}
The Saccharomyces cerevisiae prp mutants (prp2 through prp11) are known to be defective in pre-mRNA splicing at nonpermissive temperatures. We have sequenced the PRP4 gene and shown that it encodes a 52-kilodalton protein. We obtained PRP4 protein-specific antibodies and found that they inhibited in vitro pre-mRNA splicing, which confirms the essential role of PRP4 in splicing. Moreover, we found that PRP4 is required early in the spliceosome assembly pathway. Immunoprecipitation experiments with anti-PRP4 antibodies were used to demonstrate that PRP4 is a protein of the U4/U6 small nuclear ribonucleoprotein particle (snRNP). Furthermore, the U5 snRNP could be immunoprecipitated through snRNP-snRNP interactions in the large U4/U5/U6 complex.
\end{abstract}

In eucaryotes, nuclear pre-mRNA splicing requires a number of factors, including small nuclear RNA molecules (snRNAs) associated in protein complexes known as small nuclear ribonucleoprotein particles (snRNPs) (reviewed in 32 and 41). The snRNPs assemble onto the pre-mRNA substrate to form a large splicing complex known as spliceosome $(6,16,17)$. Five major snRNAs have been found to be essential for mRNA splicing (reviewed in reference 17a). The snRNPs containing U1, U2, and U5 snRNAs consist of the single snRNA complexed with several specific proteins (reviewed in reference 30 ). In contrast, the U4 and U6 snRNAs are found base paired together in the same snRNP $(4,20)$. With the exception of U6, the snRNAs possess a trimethylguanosine $\left(\mathrm{m}_{3} \mathrm{G}\right)$-modified nucleotide cap at the $5^{\prime}$ end (5). Some of the snRNPs interact directly with the precursor $(9,45)$. The U1 snRNP binds to the 5 ' splice site, the U2 snRNP binds to the branchpoint, and the U5 snRNP possibly recognizes the $3^{\prime}$ splice site. Binding of U1 and U2 snRNPs to the pre-mRNA is required in early steps of spliceosome formation. In a later step, the U4/U6 snRNP is required for splicing; however, no association with the pre-mRNA at a specific site has been identified, and the role of the U4/U6 complex is still unknown.

Most aspects of mRNA splicing are conserved between yeast and mammalian systems. Spliceosome assembly occurs by the same general pathway, which involves splicingdependent complexes in both systems $(11,21,38)$. The snRNAs in yeast cells are larger than their mammalian counterparts, but they contain similar functional domains. In mammals, the protein components of the spliceosome include heterogeneous nuclear RNPs (12) and several snRNPs: seven core proteins common to all snRNPs and some unique proteins specific to each snRNP (reviewed in reference 30 ). However, specific functions have not been determined for any of them, nor have all of the proteins involved in splicing been identified. In yeast cells, pre-mRNA splicing also requires multiple protein factors, but less is known about these factors. Identification of several proteins required in yeast pre-mRNA splicing has been possible through the study of the yeast rna mutants (rna2 to rnall), which were first identified by Hartwell and are known to be defective in mRNA splicing at nonpermissive temperatures (19). These

\footnotetext{
* Corresponding author.
}

mutants are now called pre-mRNA-processing ( $p r p$ ) mutants by researchers in the field. The protein products of several of the $P R P$ genes have been shown to be directly involved in the yeast mRNA-splicing process: antibodies directed against PRP8 immunoprecipitate specific snRNAs (29), PRP11 is found to be associated with the spliceosome (10), and PRP2 appears to be an extrinsic spliceosome factor required at a late stage of spliceosome formation (27). As yet, however, no specific function has been described for any protein involved in splicing. We have examined the role of one of the PRP gene products, the PRP4 protein, in mRNA splicing and its relationship with the other components of the spliceosome. The PRP4 gene has been previously cloned by genetic complementation, and a 1.6-kilobase transcript of low abundance has been identified (44). In this paper, we demonstrate that the PRP4 gene encodes a 52 -kilodalton $(\mathrm{kDa})$ protein that is essential for in vitro mRNA splicing and is required early in the spliceosome pathway. By using anti-PRP4 antibodies, we show that the large U4/U5/U6 snRNP complex can be immunoprecipitated. We provide evidence that PRP4 is strongly associated with the U4/U6 snRNP.

\section{MATERIALS AND METHODS}

Strains. Escherichia coli JM101 [ $\Delta$ (lac-pro) thi supE $\left(\mathrm{F}^{\prime}\right.$ traD36 proA $^{+} B^{+}$, lacI ${ }^{\mathrm{q}}$ lacZ $\left.\left.Z \mathrm{M} 15\right)\right]$ was used for cloning and amplification of plasmid DNAs, and strain AR58 (34) was used for expression of PRP4. The Saccharomyces cerevisiae strains DBY689 (a leu2.3,2-112 ura3-50 canl-101) and B364B ( $\alpha$ adel ade2 lys2 tyrl his7 ural gall) were used for preparation of splicing extracts.

mRNA-splicing assay. mRNA-splicing extracts were prepared as described by Lustig et al. (31). Actin precursor was synthesized in vitro by using SP6 polymerase as described by Lin et al. (28). Splicing reactions were carried out in a buffer containing $60 \mathrm{mM} \mathrm{KPO}_{4}(\mathrm{pH} 7), 3 \mathrm{mM} \mathrm{MgCl} \mathrm{M}_{2}, 1 \mathrm{mM}$ spermidine, $2 \mathrm{mM}$ ATP, $3 \%$ polyethylene glycol (PEG), 0.4 $\mathrm{nM}$ transcript, and $40 \%$ splicing extract, as previously described by Newman et al. (35).

Sequencing and sequence analysis. The sequence of PRP4 was determined by subcloning HindIII-BgIII, BalI-HindIII, $B g l \mathrm{II}-P s t \mathrm{I}$, and $B g$ lII-BglII fragments into $\mathrm{M} 13 \mathrm{mp} 18$ or M13mp19 and sequencing both strands by the dideoxynucleotide method (40). Sequences overlapping the restriction 
sites and sequences far from the universal primer were determined by using synthetic oligonucleotides as primers. Sequence data were assembled, translated, and analyzed with the GENED, SEQ, and PEP programs of the BIONET National Computer Resource for Molecular Biology. All protein sequences used in homology searches were obtained with the Intelligenetics QUEST, IFIND, and XFASTP programs of the National Institutes of Health sequence and National Biomedical Research Foundation protein data bases in BIONET.

Plasmid construction. Plasmid pJDB207/PRP4, containing the wild-type PRP4 gene, was constructed from a 5.6kilobase BamHI fragment cloned into pJDB207. This plasmid was kindly provided by J. Woolford, Carnegie-Mellon University, Pittsburgh, Pa. Plasmid M13mp18/PRP4 was constructed by subcloning a 2.1-kilobase HindIII-BalI fragment, capable of complementing the prp4 mutation in trans (44), into the HindIII and HindII sites of M13mp18. Two oligonucleotides with the following sequences were synthesized and used to introduce an $N c o$ I site precisely at the $5^{\prime}$ and $3^{\prime}$ ends of the PRP4 gene: 5'-ATATTTACCCATGGTC CGTTC-3' (21-mer used to introduce NcoI upstream) and 5'-TACTAAATCCATGGCTTTACAC-3' (22-mer used to introduce Ncol downstream). One of the base changes modifies the second codon (AGT, serine to GGT, glycine). The NcoI fragment was inserted in the NcoI cloning site of the PAR3039/1 vector, a derivative of PAR3039 (49) in which the unique $N d e$ I site was destroyed by Klenow filling and a unique $\mathrm{NcoI}$ cloning site was created by insertion of $\mathrm{NcoI}$ linkers (5'-CAGCCATGGCTG-3').

Expression of the PRP4 gene in $\boldsymbol{E}$. coli. The expression system used consisted of the two compatible plasmids PAR3039/1 and pGP1-2. Plasmid pGP1-2 carries the T7 RNA polymerase gene under the control of the $p_{\mathrm{L}}$ promoter of bacteriophage $\lambda$ and the $\lambda c I 857$ gene under the control of plac promoter. Plasmid pGP1-2 allows expression of the T7 polymerase after heat induction. The expression experiments were done essentially as described by Zerbib et al. (49). A 5-ml culture was grown at $23^{\circ} \mathrm{C}$ in L-broth medium in the presence of isopropyl- $\beta$-D-thiogalactopyranoside (IPTG; $4 \mu \mathrm{g} / \mathrm{ml})$, ampicillin $(300 \mu \mathrm{g} / \mathrm{ml})$, and kanamycin $(60 \mu \mathrm{g} / \mathrm{ml})$. When the culture reached an $A_{600}$ of 0.5 , the cells were harvested, suspended in medium without IPTG, and shifted to $42^{\circ} \mathrm{C}$ for $30 \mathrm{~min}$ to inactivate the heat-sensitive $\lambda$ repressor, followed by growth at $23^{\circ} \mathrm{C}$ for $16 \mathrm{~h}$. To monitor the production of PRP4, aliquots of the culture were centrifuged and suspended in Tris-sucrose buffer (10 mM Tris [pH 7.4], $10 \%$ sucrose); typically $80 \mu \mathrm{l}$ of buffer was added per $\mathrm{ml}$ of culture for every unit of optical density at $600 \mathrm{~nm}$. Loading buffer was added to the cells, the samples were boiled for 3 min, and 20- $\mu$ l samples were loaded on a sodium dodecyl sulfate (SDS)-10\% polyacrylamide gel. Proteins were stained with Coomassie blue.

Production of PRP4 antibody and immunoblot analysis. Four liters of culture of the overproduced $E$. coli strain was grown in the conditions described above. The cells were collected by centrifugation, washed, and suspended in buffer

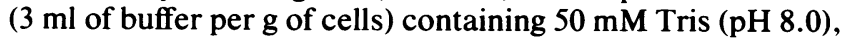
$5 \mathrm{mM}$ EDTA, $1 \mathrm{mM} \beta$-mercaptoethanol, $4 \%$ glycerol, and 1 $\mathrm{mM}$ phenylmethylsulfonyl fluoride. The cells were treated with lysozyme for $1 \mathrm{~h}$ at $4^{\circ} \mathrm{C}$ and then were broken by freeze-thawing and sonication. The lysate was centrifuged, the supernatant was discarded, and the pellet was suspended in Tris-sucrose buffer ( $1 \mathrm{ml}$ of buffer per $\mathrm{g}$ of cells) containing $50 \mathrm{mM}$ Tris (pH 8.0), $5 \mathrm{mM}$ EDTA, $1 \mathrm{mM} \beta$-mercaptoethanol, $4 \%$ glycerol, and $0.5 \%$ SDS. After centrifugation at
$17,000 \mathrm{rpm}$ in a Sorvall SS34 rotor for $30 \mathrm{~min}, 100 \mu \mathrm{l}$ of the supernatant was loaded on an SDS-10\% polyacrylamide gel ( 25 by 12 by $0.15 \mathrm{~cm})$. Electrophoresis was carried out at 100 $\mathrm{V}$ for $20 \mathrm{~h}$. Proteins were stained with Coomassie blue and destained briefly; the band corresponding to PRP4 was cut from the gel, crushed, and treated as described by Phizicky et al. (37). Protein $(100 \mu \mathrm{g})$ was injected subcutaneously into a young New Zealand White rabbit. Boosts of the same amount of material were injected after 1 month and every 2 weeks for an additional month. The antibodies obtained were used in immunoblot analysis to detect PRP4 in yeast extract or in crude lysate prepared from the PRP4-overproducing $E$. coli strain. The procedure of electroblotting proteins onto nitrocellulose filters and visualizing with rabbit antibody and goat anti-rabbit antibody coupled to horseradish peroxidase has been described previously $(14,48)$.

Antibody inhibition of mRNA splicing in vitro. Antibody inhibition of mRNA splicing in vitro was done as described by Chang et al. (10). Yeast extract $(4 \mu \mathrm{l})$ was mixed with $3 \mu \mathrm{l}$ of protein A-purified antibodies $(0.2$ to $20 \mu \mathrm{g})$ and incubated at $4^{\circ} \mathrm{C}$ for $30 \mathrm{~min}$. A solution containing ${ }^{32} \mathrm{P}$-labeled premRNA and all of the other splicing components was then added to make a final volume of $10 \mu$ l. The splicing reactions were carried out as previously described for $20 \mathrm{~min}$ at $23^{\circ} \mathrm{C}$, and the RNAs were separated on an $8 \%$ polyacrylamide $-7 \mathrm{M}$ urea gel, which was then subjected to autoradiography.

Analysis of splicing complexes. Splicing complexes were analyzed by nondenaturing polyacrylamide gel electrophoresis as described by Cheng and Abelson (11). Wild-type extract $(2 \mu \mathrm{l})$ was preincubated for $30 \mathrm{~min}$ at $4^{\circ} \mathrm{C}$ with either preimmune immunoglobulin $\mathrm{G}$ (IgG) or anti-PRP4 IgG purified by affinity chromatography on protein-A Sepharose, and standard splicing reactions were carried out. Just before electrophoresis, a solution containing $60 \mathrm{mM}$ potassium phosphate ( $\mathrm{pH}$ 7.0), $3 \mathrm{mM} \mathrm{MgCl}_{2}, 3 \%$ PEG 8000, 8\% glycerol, and heparin $(2 \mu \mathrm{g} / \mu \mathrm{l}$ of extract) was added to the samples. The samples were analyzed by gel electrophoresis through a 4\% polyacrylamide gel (acrylamide/bisacrylamide ratio of $80: 1$ ) at $300 \mathrm{~V}$ for $30 \mathrm{~min}$ and then at $230 \mathrm{~V}$ for $4 \mathrm{~h}$ at $4^{\circ} \mathrm{C}$ in a buffer containing $20 \mathrm{mM}$ Tris hydrochloride $(\mathrm{pH} \mathrm{8.0)}$ and $1 \mathrm{mM}$ EDTA, as previously described (11).

Immunoprecipitation. Anti- $\mathrm{m}_{3} \mathrm{G}$ antibody was a generous gift from R. Lührmann (Max-Planck Institut, Berlin, Federal Republic of Germany). RNAs were immunoprecipitated as described by Cheng and Abelson (11) and Lossky et al. (29). Antiserum or preimmune serum was coupled to protein A-Sepharose by incubating $3 \mu \mathrm{l}$ of serum with $2.5 \mathrm{mg}$ of protein A-Sepharose (Pharmacia, Inc.) at $4^{\circ} \mathrm{C}$ for $1 \mathrm{~h}$ in 0.5 $\mathrm{ml}$ of NET-2 buffer ( $50 \mathrm{mM}$ Tris hydrochloride [pH 7.4], $0.05 \%$ Nonidet $\mathrm{P}-40,150 \mathrm{mM} \mathrm{NaCl}$ ). The resin was then washed three times with $1 \mathrm{ml}$ of the same buffer or with NET buffers of different salt molarities (between 0 and $750 \mathrm{mM}$ $\mathrm{NaCl})$. Before immunoprecipitation, yeast extract $(4 \mu \mathrm{l})$ was preincubated without substrate under splicing conditions for $20 \mathrm{~min}$ at $23^{\circ} \mathrm{C}$ in a total volume of $10 \mu \mathrm{l}$. In some experiments, heparin $(2 \mu \mathrm{g} / \mu \mathrm{l}$ of extract) was added to splicing buffer before incubation. This material was then added to the antibody-bound protein A-Sepharose and incubated for $2 \mathrm{~h}$ at $4^{\circ} \mathrm{C}$ with mixing. The resin was washed extensively with the NET buffer used previously and phenol-chloroform extracted, and the isolated RNAs were analyzed as described below.

Analysis of $3^{\prime}$-end-labeled RNAs. In vitro labeling of RNAs with $\left[5^{\prime}-{ }^{32} \mathrm{P}\right] \mathrm{pCp}$ and T4 RNA ligase was done essentially as described elsewhere (S. Ruby, S. E. Goelz, Z. Hostomsky, and J. Abelson, Methods Enzymol., in press). Immunopre- 
-211 TAGTGGTATC TGAAATATAT ATATACACAG TTTCTTAAAT TGTTGTCTTT ACTACTGGTA TTACTATCGC

-71 TGATCACTAA TCGTAACTTI GCAACGAGCC TGAGGGAAAT GACTAGTACT ATTACCTTGT TGAACGGAAT

1 ATG AGT AAA TAT ATT GCA CTT GAA AAT CTT CCG GTA GAT TTG CAA CAT AAA GGA GCT ACA

61 CAA AAT GAA AGC ACC GCT GAT ATA CTG AAA CAG TTG CCA CAT GAA CGA TTA CAA GCT GTC

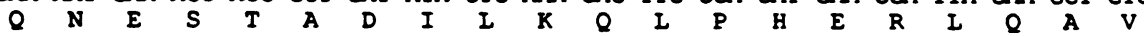

121 CTG GAG AAg ATA CCA GAA GAA GAT CTT GAG GTG AGA CGA ITG CTT TCA ATT ITA AAG AAG

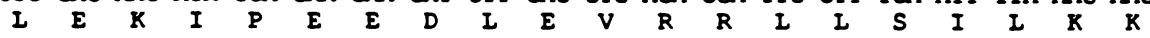

181 CCG GAA GTA GTG GAG AAT GAA GAT GTA CAA CAA AGA AGA ATA CGG ITG GCT GAA ATT TTA $\begin{array}{lllllllllllllllllllll}P & E & V & V & E & N & E & D & V & Q & Q & R & R & I & R & I & A & E & I & I\end{array}$

241 ATG GTT GAT GAA ATT GAT CTT GAG AAC ATT AAT AAC ATG GAA AAC ATA AAT GGG GAA GAA

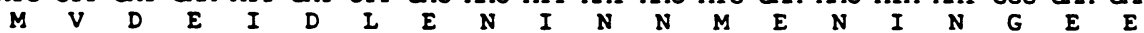

301 GTA GAC GAA GAG GAC GAT GAG GAC TTC TTC ACT CCA GCA ACA TCT GAG CTC ATT ITT GCG

361 AGA AGA TTT TTG ATA AAT TAT TCA CTT GAA AGA TCT CGA AAG AGG CTA CAG AAA GAG ATG $\begin{array}{llllllllllllllllllllll}R & R & F & I & I & N & Y & S & I & E & R & S & R & K & R & L & Q & K & E & M\end{array}$

421 GAA AGA CAT CAA AAG TTC AAT ACA AGA CAG GAA TTA CTC AGT CGG CGT ACA GAA TTA CAG $\begin{array}{llllllllllllllllllll}E & R & H & Q & K & F & N & T & R & Q & E & L & I & S & R & R & T & E & I & Q\end{array}$

481 CGT ATG GCT AAT TTA GAG CTT GCT GGC TCT CAA TTA GTA TCT ACG AAG CCT ATT TCC GCA

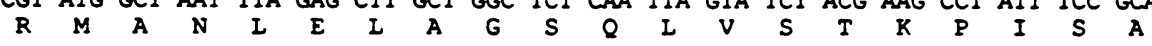

541 GTT TCT TTA TCT ACC GAT GAC ATG GTT GTC GCA ACG GGA AGC TGG GCA GGT GAT CTT CAG $\begin{array}{lllllllllllllllllllll}V & S & I & S & T & D & D & M & V & V & A & T & G & S & W & A & G & D & I & Q\end{array}$

601 GTA TTA AAT TCT CAA ACA CTG CAG CCA TTG ACA CAA AAA CTC GAC TCT CAT GTA GGG AAA

661 ATC GGA GCT ATA GAT TGG CAT CCT GAT TCA AAC AAT CAA ATG ATT ICA TGC GCA GAA GAC

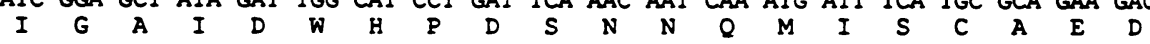

721 GGG CTC ATC AAA AAC TIT CAA TAC TCA AAC GAA GAG GGC GGC CTT CGA ITA TTG GGA GAT

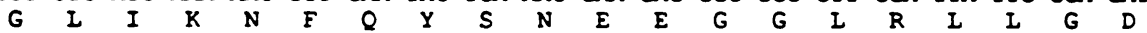
781 CTT GTG GGA CAT GAA AGA CGT ATT TCT GAT GTG AAA TAC CAC CCT AGT GGC AAA TTT ATA

841 GGT AGT GCC TCT CAT GAT ATG ACT TGG AGA CTT TGG GAT GCG TCA ACA CAT CAA GAA CTG

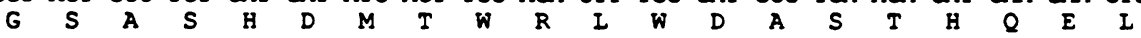

901 CTG CTA CAA GAA GGC CAT GAT AAG GGA GTG TTT AGT CTG ICT ITT CAA TGC GAT GGA TCT

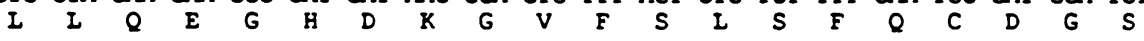

961 CTT GTT TGT AGC GGT GGC ATG GAC TCG CTT TCA ATG CTA TGG GAT ATA AGA TCC GGA AGT $\begin{array}{llllllllllllllllllllll}I & V & C & S & G & G & M & D & S & I & S & M & I & W & D & I & R & S & G & S\end{array}$

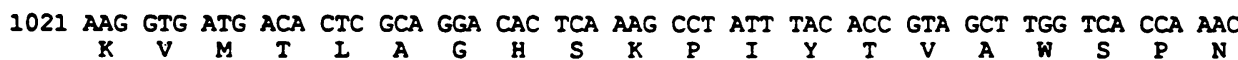

1081 GGG TAT CAA GTA GCC ACT GGT GGT GGT GAT GGA ATC ATT AAT GTT IGG GAC ATC AGA AAA

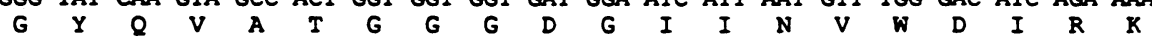

1141 CGG GAT GAA GGC CAA CTA AAT CAA ATA TTG GCG CAT CGT AAC ATC GTT ACG CAG GTA AGG

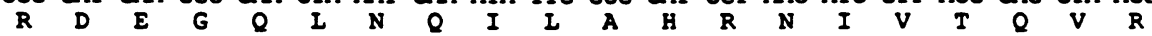

1201 TTT TCA AAG GAA GAC GGC GGA AAG AAA CTT GTC TCT TGT GGC TAT GAT AAT TTG ATC AAT

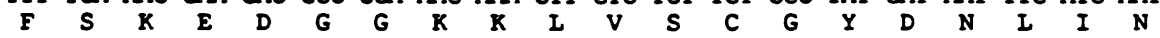

$1261 \underset{V}{G T G}$ TAT AGT AGT GAT ACG TGG TIA AAA ATG GGA AGT TTA GCA GGC CAC ACT GAT AAA ATT

1321 ATT AGC TTG GAT ATT TCG AAT AAT TCT CAT TTT TTA GTG AGC GGC GGA TGG GAT AGG TCT

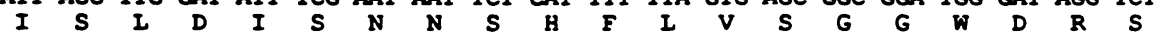

1381 ATC AAG CTC TGG AAT TGA TTGTGTAAAG AAATGTATTT AGTATTTTTG AAACTAACGT TITATTAACA

1449 CTGCATTATT TATTTAATTA TACATTTCCT GGTTTTTTTG CCCTGGATTT TITTITTGTG TTACCATTTT

1519 GAGTACGAAC TCGTGGAATT GTTAAGTTTT CCAAGTTGTC CATCGTCTTC GATAACTGTC CCACTAACTC

FIG. 1. Sequence of PRP4, including the PRP4-coding sequence as well as the $5^{\prime}$ - and $3^{\prime}$-flanking regions. The nucleotide sequence and the deduced amino acid sequence are shown. The DNA sequence is numbered starting from the first nucleotide of the initiation codon (ATG). The underlined sequences represent the complementary sequences of the oligonucleotides used for site-specific mutagenesis. 
cipitated RNAs were purified by phenol-chloroform extraction and ethanol precipitation in the presence of glycogen as a carrier (20 $\mu \mathrm{g}$ per reaction). These RNAs were added to a $10-\mu$ l reaction mixture containing cytidine $3^{\prime}, 5^{\prime}-\left[5^{\prime}-{ }^{32} \mathrm{P}\right]$ bisphosphate $(80 \mu \mathrm{Ci} ; 3,000 \mathrm{Ci} / \mathrm{mmol})$ in $30 \mathrm{mM} \mathrm{N}$-2-hydroxyethylpiperazine- $N$-2' -ethanesulfonic acid (HEPES; pH 8.3)$6 \mathrm{mM} \mathrm{MgCl}_{2}-4 \mathrm{mM}$ dithiothreitol-12 $\mu \mathrm{M}$ ATP-dimethyl sulfoxide-10\% 5\% PEG 8000 . The ligation reaction was carried out for $4 \mathrm{~h}$ at room temperature in the presence of 20 $\mathrm{U}$ of RNasin (Promega Biotec). After ethanol precipitation, the RNAs were separated by electrophoresis on a $6 \%$ polyacrylamide-7 M urea gel with an acrylamide/bisacrylamide ratio of $29: 1$, followed by autoradiography.

Northern (RNA) blot analysis. RNAs from the gel were electroblotted onto GeneScreen membrane (Dupont, NEN Research Products) in $25 \mathrm{mM}$ phosphate buffer (pH 6.5) for 16 to $18 \mathrm{~h}$ at $4^{\circ} \mathrm{C}$ and UV irradiated for $10 \mathrm{~min}$ to fix the RNAs (13). Prehybridization and hybridization of blots were carried out at $42^{\circ} \mathrm{C}$ in a solution containing $50 \%$ formamide, $25 \mathrm{mM}$ sodium phosphate (pH 6.5), 6× SSC (SSC is $0.15 \mathrm{M}$ $\mathrm{NaCl}$ plus $0.015 \mathrm{M}$ sodium citrate), $5 \times$ Denhardt solution, $0.5 \%$ SDS, and $0.1 \mathrm{mg}$ of calf thymus DNA per ml. After hybridization, membranes were washed twice for 5 min each in $2 \times \mathrm{SSC}-0.5 \% \mathrm{SDS}$, twice for $5 \mathrm{~min}$ each in $2 \times \mathrm{SSC}-0.1 \%$ $\mathrm{SDS}$ at room temperature, and once for $30 \mathrm{~min}$ at $60^{\circ} \mathrm{C}$. The $\mathrm{U} 4$, U5, and $\mathrm{U} 6$ probes were ${ }^{32} \mathrm{P}$ end labeled by treating 20 pmol of synthetic oligonucleotides with polynucleotide kinase as described by Maxam and Gilbert (33). The following oligonucleotides were used as probes: a 45-mer (5'-ATT CAAAGCGAACACGAATTGACCATGAGGAGACGGTC TGGTTTA-3') complementary to residues 77 to 121 of yeast U4 snRNA (42), a 35-mer (5'-CCTGTTTCTATGGAGACA ACACCCGGATGGTTCTG-3') complementary to residues 101 to 136 of yeast U5 snRNA (36) and a 49-mer (5'-CAT CCTTATGCAGGGGAACTGCTGATCATCTCTGTATTG TTTCAAATTG-3') complementary to residues 34 to 82 of yeast U6 snRNA (7). DNA fragments containing U1 $(25,43)$ or a portion of the U2 (1) gene were used for synthesis of the probes by the random-primer extension method of Feinberg and Vogelstein (15). The U2 clone was provided by M. Ares, and the U1 clone was provided by P. G. Siliciano.

\section{RESULTS}

Sequence of the PRP4 gene. We determined the DNA sequence of both strands of the cloned yeast PRP4 gene by the sequencing strategy described in Materials and Methods. Figure 1 summarizes the DNA sequence of the gene and the deduced amino acid sequence of the protein product.

Analysis of the sequence showed a single long open reading frame 1,400 base pairs in length that could encode a 465-amino-acid protein with a predicted molecular weight of 52,418 . A potential TATA box was found at about 190 nucleotides upstream of the ATG, and a T-rich transcription termination sequence was found around 90 to 100 nucleotides downstream of the stop codon. The sequence surrounding the ATG fit the consensus sequence (AANATGNNT) for highly expressed genes in yeast cells (18) but was not maximal; PRP4 was not abundantly produced in yeast cells.

The PRP4 protein sequence was compared with a collection of protein sequences in the BIONET data bases and with the other known PRP protein sequences; no significant homology was found.

Overproduction of PRP4 mediated by the T7 promoter in $E$. coli. The PRP4 gene was inserted into the $E$. coli expression
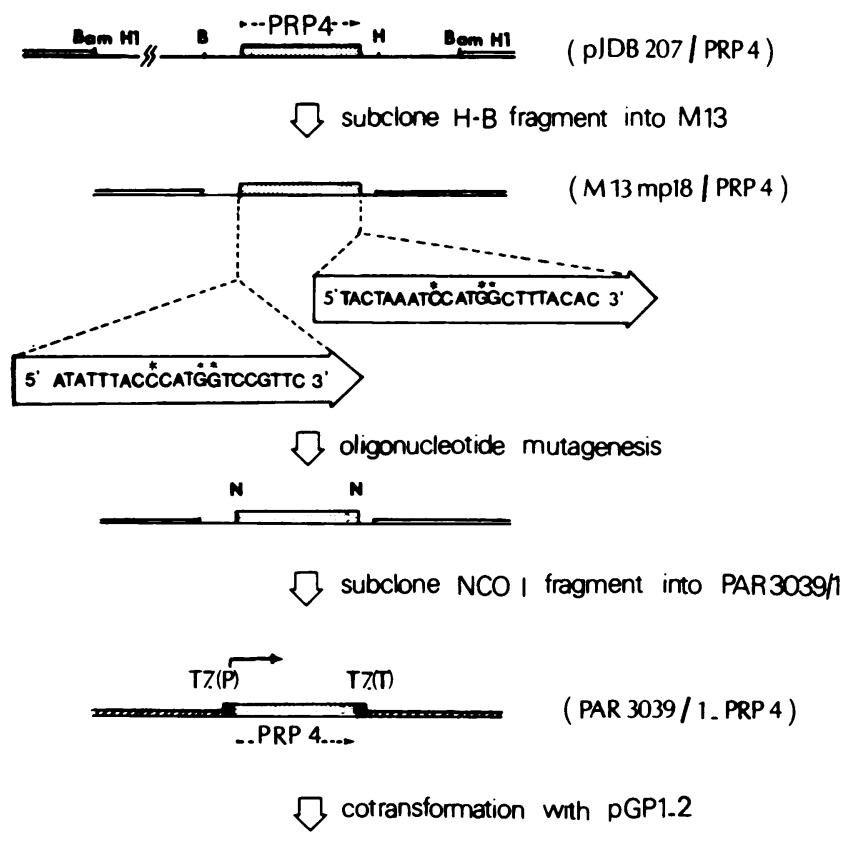

overproduction of PRP 4 in E.coli

$$
\frac{\text { SCALE }}{1 \mathrm{~kb}}
$$

FIG. 2. Scheme for construction of the expression vector. The Ball-HindIII fragment from pJDB207/PRP4 was subcloned into an M13mp18 vector. Site-specific mutagenesis was used to introduce an NcoI site on both sites of the coding fragment. The asterisks indicate base changes in the gene. The oligonucleotide sequences are the reverse complement of the DNA sequence presented in Fig. 1. The expression vector was obtained by inserting the NcoI DNA fragment into the unique cloning site of PAR3039/1 downstream of the T7 polymerase promoter. Cotransformation with pGP1-2 and PAR3039/1-PRP4 is required for overproduction of PRP4 in $E$. coli. Sites for restriction enzymes used in cloning: B, BalI; H, HindIII; $\mathrm{N}$, NcoI. Positions of the T7 promoter T7(P) and the T7 transcription terminator $\mathrm{T} 7(\mathrm{~T})$ are indicated.

vector PAR3039/1 under the control of the strong T7 transcription-translation signals through the series of manipulations shown in Fig. $2(46,47)$. The expression system used consisted of the two compatible plasmids PAR3039/1 and pGP1-2, described in Materials and Methods. When supplied with the $\mathrm{T} 7$ polymerase in trans, PAR3039/1-PRP4 was found to direct the synthesis of a large amount of PRP4, observed as a strong band of $52 \mathrm{kDa}$ on SDS-polyacrylamide gels (Fig. 3A). In the absence of pGP1-2, or with a truncated PRP4 gene (not shown), this 52-kDa band was not present. When cultures of $E$. coli(PAR3039/1-PRP4)(pGP1-2) were not induced, a low amount of PRP4 was detected, presumably as a result of synthesis of a small amount of T7 RNA polymerase.

There was a high level of expression of PRP4 in this construct; PRP4 constituted 5 to $10 \%$ of the total cellular protein in an induced culture. Like many proteins overproduced in $E$. coli, PRP4 was insoluble in the absence of detergent. We took advantage of this property during purification by reextracting the cell pellet with $0.5 \%$ SDS; this provided a useful step in the purification scheme for this protein.

Figure 3B shows the immunoblot analysis of a crude extract prepared from the overproducing strain. A very 


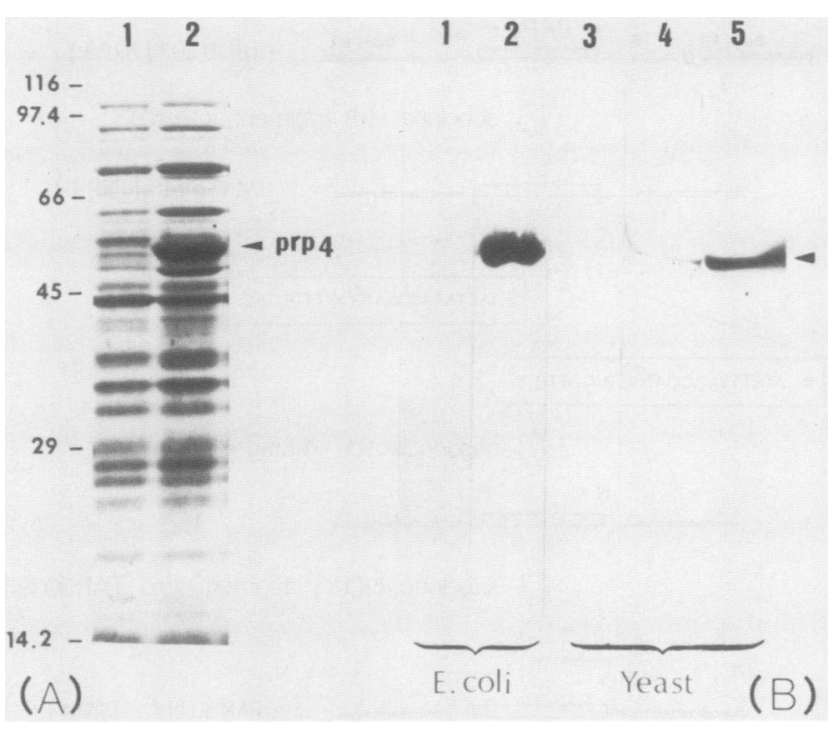

FIG. 3. Overproduction of the PRP4 protein in E. coli and Western blot (immunoblot) analysis of proteins in the $E$. coli overproducing strain and in yeast cells. (A) Accumulation of PRP4 in an overproducing strain. The two lanes represent total proteins from cells harboring the plasmid PAR3039/1-PRP4 (lane 1, in the absence of pGP1-2; lane 2, after heat induction and in the presence of pGP1-2). Samples were equivalent to $200 \mu \mathrm{l}$ of culture and were analyzed on SDS-polyacrylamide gels stained with Coomassie blue. Positions of molecular size markers are indicated on the left (in kilodaltons). (B) Immunoblot analysis. Extract from the PRP4overproducing strain (equivalent of $50 \mu \mathrm{g}$ of cells). was electrophoresed on an SDS-polyacrylamide gel, transferred to nitrocellulose, and hybridized with preimmune serum (lane 1) or with antiserum against PRP4 (lane 2) at a dilution of 1:20,000. A 40- $\mu$ l sample of yeast splicing extract from the wild-type strain and $10 \mu \mathrm{l}$ of yeast extract from the strain transformed with pJDB207/PRP4 was immunoblotted and incubated with anti-PRP4 antibodies at a dilution of 1:2,500 (lanes 4 and 5, respectively). The control with preimmune serum (lane 3) was run in parallel. Positions of the PRP4 protein are indicated $(\boldsymbol{\Delta})$. strong band could be easily detected by the anti-PRP4 antibodies used at a 1:20,000 serum dilution (lane 2). In absence of pGP1-2, no protein was detected (lane 1). Moreover, no band corresponding to this molecular weight could be detected by the preimmune serum used at the same dilution; only a few faint bands corresponding to nonspecific cross-reacting species of low molecular weight could be found (not shown).

Immunoblot analysis of yeast extracts. The anti-PRP4 antibodies appeared to react specifically with a single protein of the yeast splicing extract (Fig. 3B, lane 4). The intensity of the band observed on the immunoblot increased when the experiment was done with a strain transformed with a multicopy plasmid carrying the PRP4 gene (lane 5). At antibody concentrations higher than the 1:2,500 dilution shown, some cross-reacting species of lower molecular weight appeared. The anti-PRP4 antibodies, however, were clearly specific for yeast PRP4. No proteins were detected with the preimmune serum (lane 3 ).

Requirement of PRP4 for in vitro mRNA splicing. An antibody inhibition experiment was used to determine whether PRP4 plays a critical role in the in vitro mRNAsplicing reaction. The in vitro mRNA-splicing reaction was completely inhibited by the addition of 7.5 to $20 \mu \mathrm{g}$ of PRP4 protein A-purified antibody to $4 \mu \mathrm{l}$ of splicing extract (Fig. 4). In contrast, addition of preimmune serum had no effect on splicing.

U4, U5, and U6 snRNAs coprecipitate with PRP4. The possibility that PRP4 is associated with snRNAs was investigated by immunoprecipitation of yeast extracts with antiPRP4 antibodies at various ionic strengths. The RNA species immunoprecipitated were analyzed by Northern blotting, using labeled snRNA probes. When the immunoprecipitation was done at $150 \mathrm{mM}$ salt, three snRNAs corresponding to U4, U5 (short and long forms), and U6 were found (Fig. 5, lanes 4 and 5). There was an increase in the precipitation of $U 4$ and $U 6$ if the splicing extract was first incubated with $2 \mathrm{mM}$ ATP. Preimmune serum did not precipitate any snRNA (lanes 2 and 3). Anti- $m_{3} G$ antibodies also immunoprecipitated the U4, U5, and U6 snRNAs in addition to $U 1$ and $U 2$ snRNAs (lane 6 ) as a consequence of

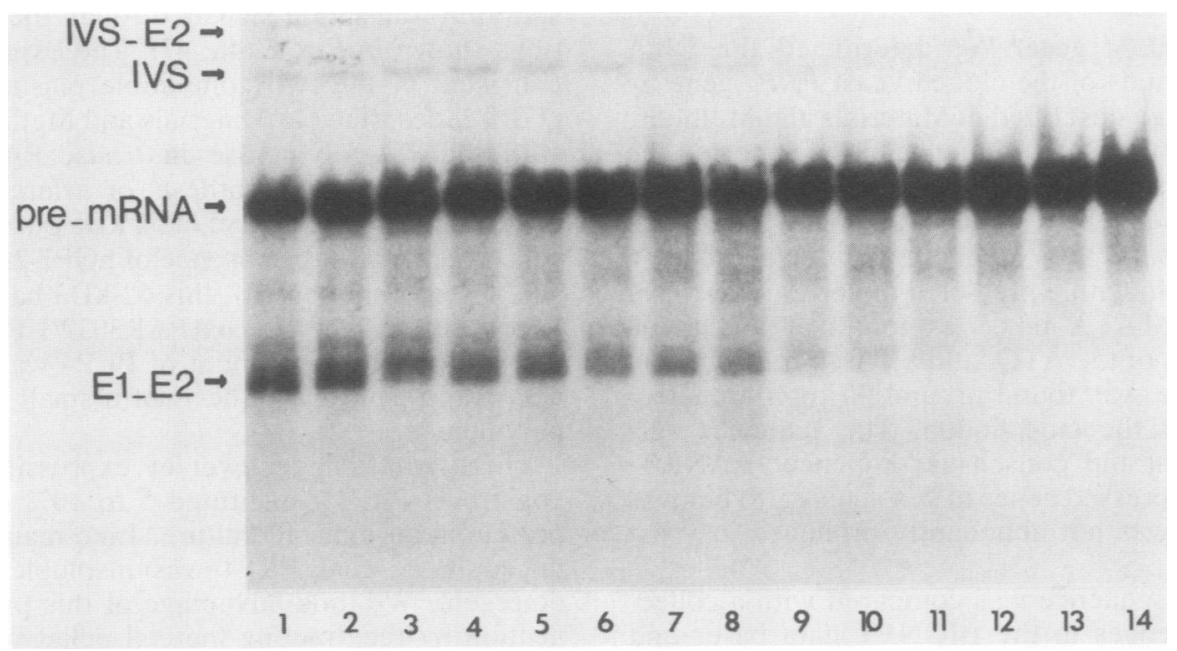

FIG. 4. Inhibition of mRNA splicing by anti-PRP4 antibodies. Wild-type splicing extract $(4 \mu \mathrm{l})$ was preincubated with buffer D (lane 1$)$, with 3 or $15 \mu \mathrm{g}$ of preimmune IgG (lanes 2 and 3 ), or with $0.2,0.3,0.5,0.7,1,3,5,7.5,10,15$, or $20 \mu g$ of anti-PRP4 IgG (lanes 4 to 14 ) for 30 min at $4^{\circ} \mathrm{C}$. A standard mRNA-slicing reaction was then carried out by using uncapped actin pre-mRNA as substrate, and the RNAs were analyzed on an $8 \%$ acrylamide-7 M urea gel. IVS-E2, Lariat intron-exon 2; IVS, excised lariat intron; E1-E2, spliced message. 


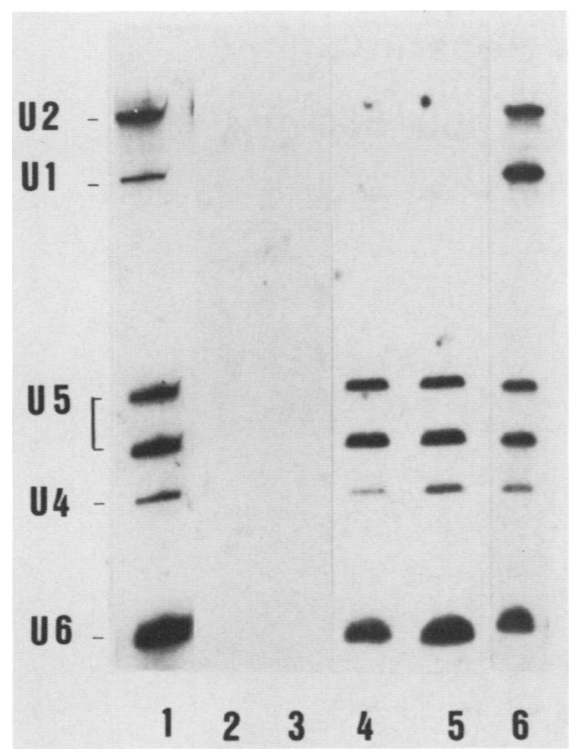

FIG. 5. Coprecipitation of snRNAs with PRP4. Splicing extract $(4 \mu \mathrm{l})$ was preincubated at $23^{\circ} \mathrm{C}$ for 20 min under splicing conditions in the absence of ATP (lanes 2 and 4 ) or in the presence of $2 \mathrm{mM}$ ATP (lanes 3, 5, and 6) and then subjected to immunoprecipitation with preimmune serum (lanes 2 and 3) anti-PRP4 antibodies (lanes 4 and 5), or anti- $\mathrm{m}_{3} \mathrm{G}$ antibodies (lane 6). Incubation of the extract with antibodies and subsequent washes were done in $150 \mathrm{mM}$ salt. RNAs were recovered from immune complexes, analyzed by electrophoresis on a $6 \%$ acrylamide-7 $\mathrm{M}$ urea gel, and probed with labeled snRNA probes as described in Materials and Methods. Lane 1 shows total RNAs from $0.5 \mu \mathrm{l}$ of crude splicing extract.

the trimethylguanosine cap structure at their $5^{\prime}$ ends. U6 has no cap structure, but it can be immunoprecipitated because of its association with U4 (42). The snRNA species precipitated by the anti-PRP4 antibodies or by the anti-m $m_{3} G$ antibodies were in the same relative proportions as observed in the total snRNAs found in the splicing extract. However, the amount of snRNAs immunoprecipitable by anti-PRP4 antibody represented only 10 to $15 \%$ of the total snRNAs.

Other snRNAs coprecipitate with PRP4 at low ionic strengths. Since snRNAs coprecipitated with PRP4, it was interesting to analyze which snRNAs were immunoprecipitated under less stringent conditions. Surprisingly, in the absence of salt, all of the snRNAs precipitated with PRP4 (data not shown); U1 and U2 were particularly abundant under these conditions. The amount of $\mathrm{U} 1$ and $\mathrm{U} 2$ precipitated decreased progressively when the salt concentration was raised to $85 \mathrm{mM}$ (data not shown).

To determine whether these results reflected specific interactions between PRP4 and the snRNAs, all of the RNAs recovered from the immunoprecipitates were $3^{\prime}$ end labeled and then analyzed by urea-gel electrophoresis. A marked increase in the amount of RNA contaminants, as well as other snRNAs immunoprecipitated with anti- $m_{3} G$ or antiPRP4 antibodies, was observed at lower ionic strengths. When the immunoprecipitation was done at $50 \mathrm{mM} \mathrm{NaCl}$ or in the absence of salt, U1, U2, U4, and U5 were immunoprecipitated along with some other snRNAs and $5 \mathrm{~S}, 5.8 \mathrm{~S}$, and large rRNAs (Fig. 6). When the stringency of the immunoprecipitation conditions was raised, the contaminants in the immunoprecipitation decreased, as did the amount of $\mathrm{U} 1$ and $\mathrm{U} 2$ precipitated. Only U4 and U5 were visible after immunoprecipitation with anti-PRP4 antibodies at $150 \mathrm{mM} \mathrm{NaCl}$; the other snRNAs were no longer immu-

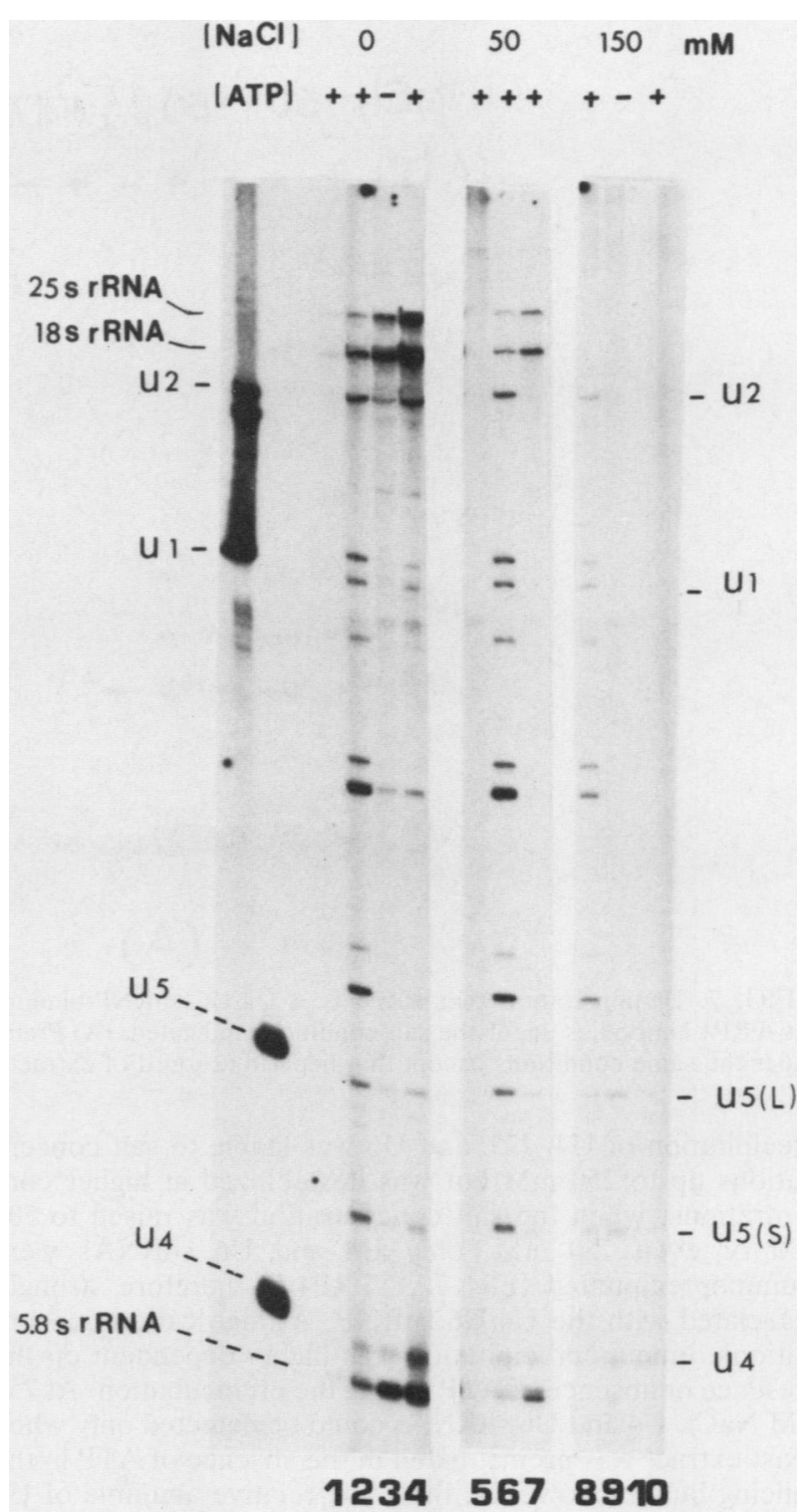

FIG. 6. Coprecipitation of the U1, U2, U5, and U4/U6 snRNPs with PRP4 in low salt. After preincubation in the absence or presence of $2 \mathrm{mM}$ ATP as indicated, splicing extracts were subjected to immunoprecipitation with preimmune serum (lanes 1 and 5), anti- $\mathrm{m}_{3} \mathrm{G}$ antibodies (lanes 2,6 , and 8), or anti-PRP4 antibodies (lanes $3,4,7,9$, and 10$)$ under different salt conditions $(0,50$, or 150 $\mathrm{mM} \mathrm{NaCl}$ ). The RNAs recovered from the immune complexes were labeled in a standard $3^{\prime}$-end-labeling reaction. The two first lanes show the in vitro transcripts of the yeast U1, U2, U4, and U5 (long form) snRNAs.

noprecipitated. Because $\mathrm{U} 6$ is a poor substrate for the 3 '-end-labeling reaction, it cannot be detected by this method. No detectable snRNAs were immunoprecipitated with the preimmune serum. In summary, we showed that the PRP4 protein could be coprecipitated with the five snRNAs under low ionic strength conditions; RNA contaminants were also precipitated but to a lesser extent.

PRP4 is strongly associated with U4/U6 snRNP. By raising the stringency of the immunoprecipitation conditions, we wanted to determine whether PRP4 was associated more specifically and more tightly with one particular snRNP. 


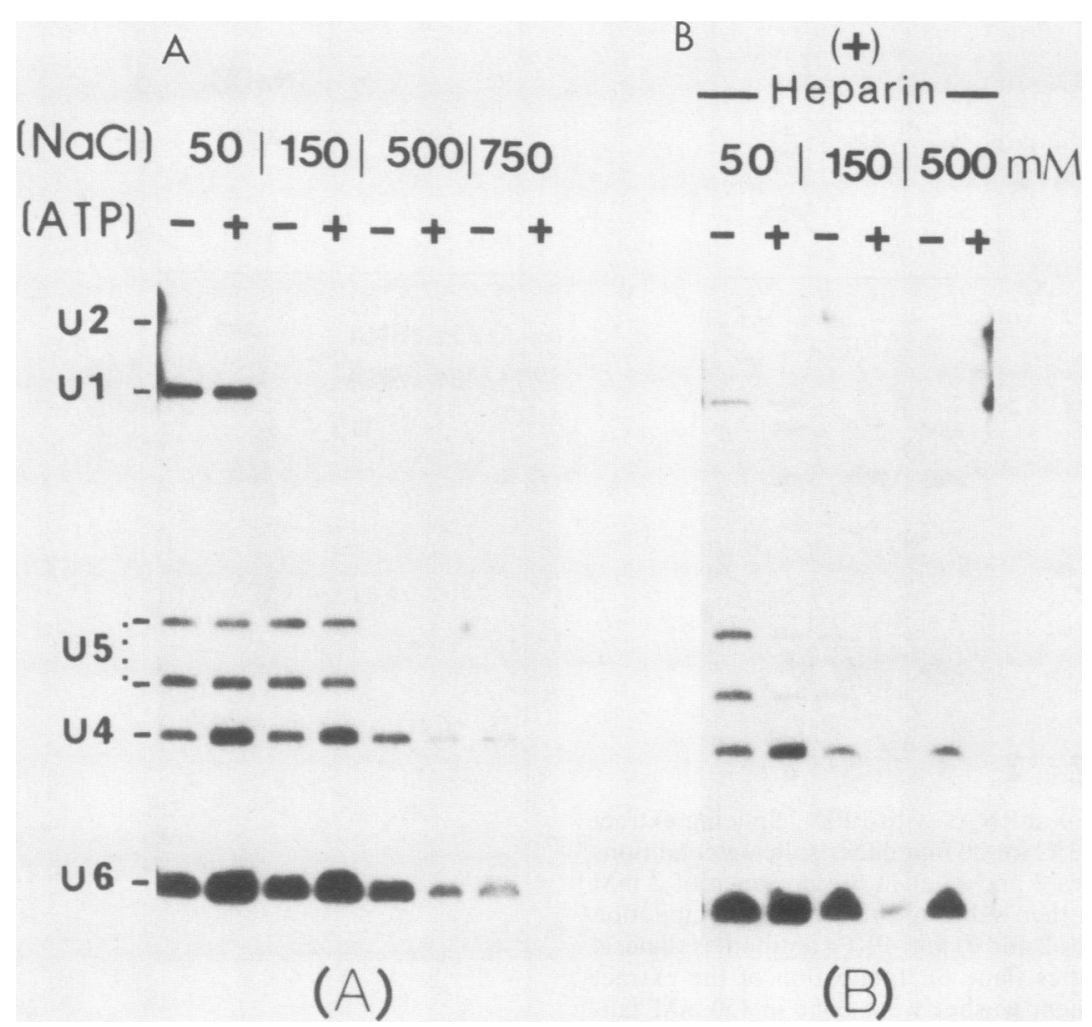

FIG. 7. Demonstration that PRP4 is a U4/U6 snRNP-binding protein. Splicing extract was subjected to immunoprecipitation with anti-PRP4 antibodies under the salt conditions indicated. (A) Preincubation in the absence or the presence of $2 \mathrm{mM}$ ATP; (B) preincubation under the same conditions except that heparin $(2 \mu \mathrm{g} / \mu \mathrm{l}$ of extract) was added.

Precipitation of U4, U5, and U6 was stable to salt concentrations up to $250 \mathrm{mM}$ but was destabilized at higher concentrations: when the salt concentration was raised to 500 $\mathrm{mM}$ or even $750 \mathrm{mM}$, only U4 and U6 snRNAs were immunoprecipitated (Fig. 7A). PRP4 is therefore strongly associated with the U4/U6 snRNP. At high cation concentrations, immunoprecipitation was highly dependent on the presence or absence of ATP during the preincubation. At 750 $\mathrm{mM} \mathrm{NaCl}, \mathrm{U} 4$ and $\mathrm{U} 6$ snRNAs could be detected only when yeast extract was preincubated in the absence of ATP in the splicing buffer. However, the same relative amounts of $\mathrm{U} 4$ and U6 snRNAs were found in the immune complexes, independently of the salt or the presence or the absence of ATP.

To confirm that PRP4 is a component of the U4/U6 snRNP, we performed the immunoprecipitation after treating the extract with heparin $(2 \mu \mathrm{g} / \mu \mathrm{l}$ of extract) as described in Materials and Methods. Heparin has previously been used to eliminate nonspecific binding of proteins to RNAs (21). Figure 7B shows the results of the immunoprecipitations done under different salt conditions. U2 was released first, which indicated that the association of U2 with PRP4 was very sensitive to heparin. Then $\mathrm{U} 1$ was released from the complex, followed by U5. It is interesting that the two forms of U5 were released at the same time. U4 and U6 were the last snRNAs to be released from the complex. Therefore, PRP4 is tightly associated with the U4/U6 snRNAs.

PRP4 is required early in the splicing pathway. Yeast actin pre-mRNA splicing studies $(11,38)$ have shown that at least four kinetically related complexes can be resolved by electrophoresis on native polyacrylamide gels. It has been shown that the earliest detectable complex (complex B [11]) contains only the U2 snRNP; then the U4, U5, and U6 snRNPs joint the complex. (The U1 snRNP could not be detected by the nondenaturing gel analysis [39]). When anti-PRP4 antibodies were added to a splicing reaction before separation of the splicing reaction mixtures on nondenaturing polyacrylamide gels, only complex B accumulated after $10 \mathrm{~min}$ of incubation (Fig. 8). The PRP4 gene product and the U5 and U4/U6 snRNPs were required for further assembly of the spliceosome. The preimmune serum had no effect on spliceosome assembly; complexes B, A1, and A2 were all observed, in accordance with the assembly pathway proposed by Cheng and Abelson (11).

\section{DISCUSSION}

Genetic and biochemical evidence has accumulated demonstrating that the protein products of the genes $P R P 2$ to $P R P I 1$ are essential components in yeast mRNA splicing and that most of the encoded proteins are required for in vitro spliceosome formation $(10,27,29,31)$; however, a specific function has not yet been determined for any of these proteins. Immunological procedures represent a powerful approach to the analysis of complexes containing a particular protein. Using this approach, Lossky et al. have been able to show that PRP8 is an snRNP protein that is specific to the U5 snRNP (29). In this study, we demonstrated that the 52-kDa protein encoded by the PRP4 gene of $S$. cerevisiae also is a component of snRNPs. We showed that PRP4 is a U4/U6 snRNP protein that is also present in the larger U4/U5/U6 complex. Moreover, we showed that PRP4 is required for in vitro mRNA splicing at an early stage in the spliceosome assembly pathway.

We have used immunoprecipitation experiments to demonstrate that PRP4 is tightly associated with U4 and U6 snRNAs. By Northern blot analysis of snRNP components on nondenaturing gels, Cheng and Abelson (11) observed 


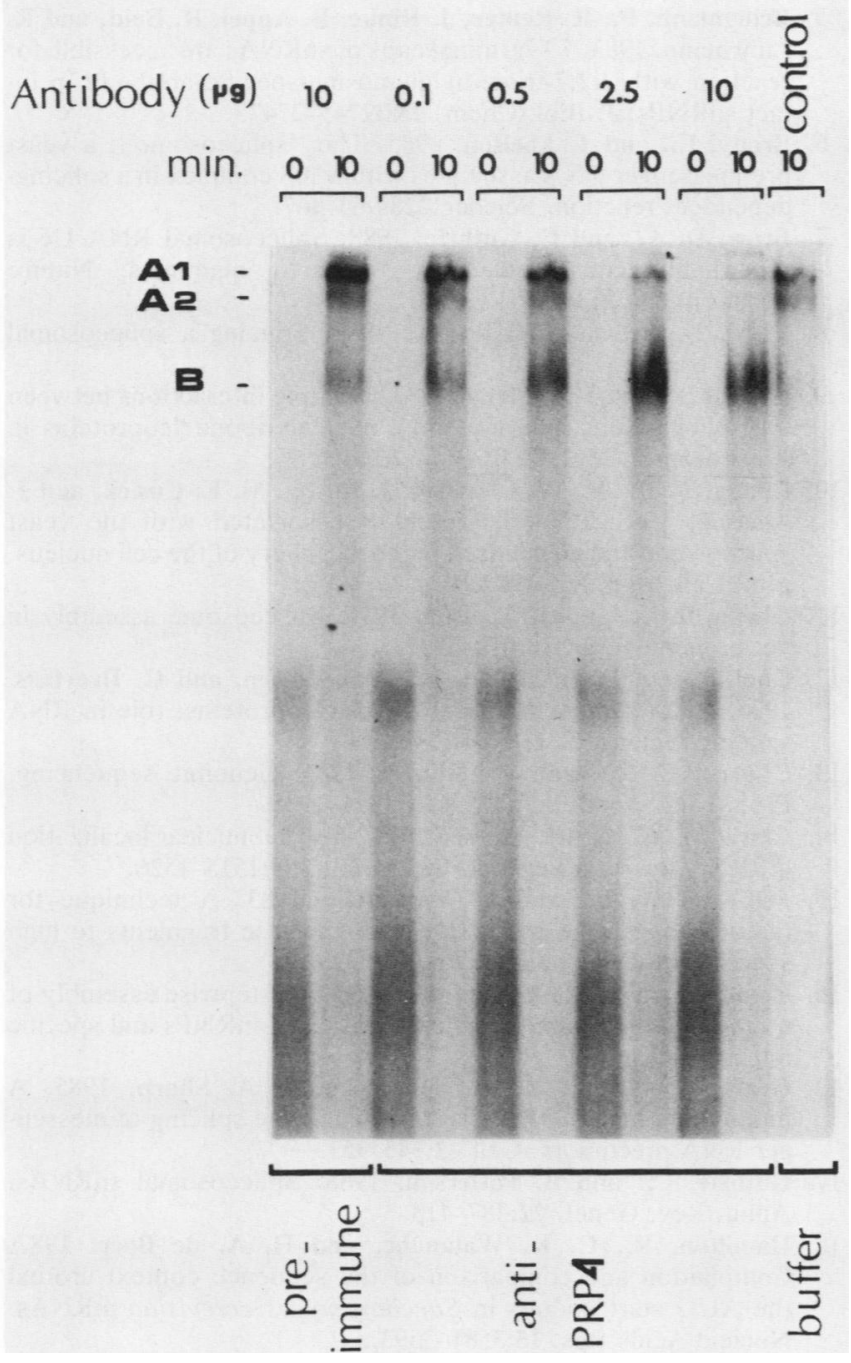

FIG. 8. Inhibition of spliceosome assembly by addition of antiPRP4 antibodies. Splicing extract $(2 \mu \mathrm{l})$ was preincubated with buffer D (control), preimmune IgG $(10 \mu \mathrm{g})$, or anti-PRP4 IgG $(0.1$, $0.5,2.5$, or $10 \mu \mathrm{g}$ ) at $0^{\circ} \mathrm{C}$ for $10 \mathrm{~min}$; then standard splicing reactions were carried out for $10 \mathrm{~min}$ at $23^{\circ} \mathrm{C}$. The complexes were separated by electrophoresis on a native polyacrylamide gel.

that U6 could exist as a separate U6 snRNP, in contrast with the "virtual absence" of separate U4 snRNP in yeast extract. The fact that U4 and U6 were always immunoprecipitated together in the same relative ratio regardless of the conditions used strongly suggests that PRP4 is a component of the U4/U6 snRNP. Furthermore, since the same relative amounts of U4 and U6 were observed both with the anti$\mathrm{m}_{3} \mathrm{G}$ and anti-PRP4 antibodies, PRP4 does not seem to be associated with the separate U6 snRNP.

PRP4 was also found to be associated with the two forms of U5 snRNA. It has previously been shown that in yeast the U4/U6 and U5 snRNPs are associated in a large U4/U5/U6 particle (11). A similar complex has been found in mammalian cells (22). In yeast cells, this particle was described as being very stable in vitro under a variety of conditions, but it could be dissociated at high salt concentrations to give a free U5 snRNP and a complex containing both U4 and U6 snRNAs (11). When the salt concentration in the immunoprecipitations was raised to $350 \mathrm{mM}$ (data not shown), U5 dissociated from the large complex, since only U4 and U6
snRNAs, not U5, were immunoprecipitated by the antiPRP4 antibodies. This result indicates that PRP4 is not a component of the U5 snRNP. The U5 snRNP can be immunoprecipitated only through snRNP-snRNP interactions. When the interactions between U5 and U4/U6 snRNPs were destabilized (by high salt concentrations or by heparin treatment), U5 was no longer immunoprecipitated. In addition, antibodies against PRP4 were able to mediate the coprecipitation of $\mathrm{U} 1$ and $U 2$ snRNAs along with the U4/U5/U6 particle at very low ionic strengths. This observation might indicate that PRP4 is associated with each snRNP, leading to precipitation of each particle independently. This seems unlikely for several reasons. First, significant amounts of other snRNAs as well as RNA contaminants (rRNAs) have been immunoprecipitated under these conditions. Second, we found no conditions under which only $\mathrm{U} 1$ or $\mathrm{U} 2$ could be immunoprecipitated. Finally, U1 and U2 were no longer precipitated when the conditions were more stringent (high salt concentrations or the presence of heparin). It seems more likely that U1 and U2 snRNAs were immunoprecipitated via snRNP-snRNP interactions with the U4/U5/U6 particle. By comparison, it is interesting to note that the anti-PRP8 antibodies were able to precipitate significant amounts of RNA contaminants but only U5 snRNA under the less stringent conditions; U1, U2, U4, and U6 were not precipitated (data not shown). A similar set of snRNPs associated in the absence of pre-RNA during incubation of the extract in $250 \mathrm{mM} \mathrm{NH}_{4} \mathrm{Cl}$ has been described in mammalian cells by Konarska and Sharp (23).

Splicing complex containing intermediates, products, and pre-mRNA could not be immunoprecipitated by the antiPRP4 antibodies under normal salt conditions but only under low-salt conditions (data not shown). The simplest interpretation of this result is that the anti-PRP4 antibodies were able to precipitate the U4/U5/U6 complex before it became associated with the pre-mRNA; once this particle became associated with the U2-pre-mRNA complex, the antigenic sites of PRP4 become inaccessible to the antibodies. At low salt concentrations, the conformation of the large complex may be different and the antigenic sites more accessible.

Our results showed that the U4/U5/U6 complex was precipitated by anti-PRP4 antibodies both in the presence and in the absence of ATP. Previously, Lossky et al. (29) observed that this complex could be precipitated by antiPRP8 antibodies only after preincubation with ATP. We are currently investigating this discrepancy. It could be due to differing procedures or to differences in the ATP level in extracts or in the endogenous level of the U4/U5/U6 complex. Cheng and Abelson (11) previously observed that the U4/U5/U6 complex, as detected on nondenaturing gels, is dissociated by ATP. The results presented here suggest that this dissociation may be a heparin-ATP effect. Treatment of extracts with heparin (at the concentration used in the nondenaturing gel separation) and ATP ( $2 \mathrm{mM})$ resulted only in the anti-PRP4 precipitation of U4 and U6 (Fig. 7B). By inducing conformational changes in the $\operatorname{snRNPs}(2,3,24)$, ATP may make the complex sensitive to dissociation by heparin.

Results of the antibody inhibition experiment confirmed those previously obtained (31) and suggest that PRP4 is essential for mRNA splicing. As was found with the anti$\mathrm{m}_{3} \mathrm{G}$ antibodies (10), the anti-PRP4 antibodies completely abolished the splicing reaction. Both steps of splicing were inhibited, indicating that the antibodies blocked the reaction before cleavage at the $3^{\prime}$ end of the upstream exon and the formation of the intron lariat. Four splicing complexes that 
form sequentially during the course of the reaction have been described (11). Complex $\mathrm{B}$, containing predominantly pre-mRNA bound to U2 snRNP, is the first detectable intermediate. Formation of the later complexes requires the association of U5 and U4/U6 snRNPs with the pre-mRNA. Removal of the snRNPs associated with PRP4 by the antibodies inhibits the formation of these complexes and results in the accumulation of complex B. This indicates that PRP4 is involved early in the spliceosome formation and is consistent with the current models for spliceosome assembly. This result also argues against the possibility that PRP4 is present in the $\mathrm{U} 1$ and $\mathrm{U} 2$ snRNPs.

In mammalian cells, no protein unique to the U4/U6 particle has yet been identified. PRP4 is the first protein described that is specific to the yeast U4/U6 snRNP. Another snRNP protein, called PRP8, that is found to be specific for the U5 snRNP has been described by Lossky et al. (29). It is interesting that the anti-PRP8 antibodies were also able to immunoprecipitate the U4/U5/U6 particle under some conditions. Up to now, PRP4 and PRP8 were the only snRNP proteins found to be involved in yeast mRNA splicing. The antibodies now make it possible to investigate the protein composition of the U4/U6 snRNP in yeast cells. It is interesting that extra copies of PRP3 (26) are able to relieve the lethality of prp4 at restrictive temperatures, suggesting that PRP4 and PRP3 may interact in the same snRNP and may have related functions. No specific binding site for the U4/U6 particle in the splicing complex has been yet identified, and its role is still unknown. The high degree of evolutionary sequence conservation in U6 snRNA (7) suggests that the $\mathrm{U} 4 / \mathrm{U} 6 \mathrm{snRNP}$ may have a central position in the splicing complex and may be in close contact with a number of components of the spliceosome (8). Moreover, there are several domains highly conserved in these two snRNAs which can constitute a recognition site for binding proteins. It will be interesting to determine whether PRP4 binds specifically to U4 or U6 and to investigate the role of PRP4 in yeast pre-mRNA splicing.

\section{ACKNOWLEDGMENTS}

We thank J. Beggs and R. Lührmann for the generous gift of anti-PRP8 and anti- $m_{3} G$ antibodies and $J$. Woolford for providing the PRP4 yeast pJDB207/PRP4 plasmid. We are grateful to S.-C. Cheng for help with nondenaturing gels and to G. Komatsoulis and G. McFarland for help with computer analysis. We gratefully acknowledge K. Tanner, P. Fabrizio, G. McFarland, and J. Arenas for critical readings of the manuscript. We also thank S. Horvath for synthesizing oligonucleotides and $\mathrm{C}$. Blagg for typing the manuscript.

J.B. was a recipient of NATO and CNRS/NSF fellowships. This work was supported by Public Health Service grant GM 32637 from the National Institute of Health.

\section{LITERATURE CITED}

1. Ares, M. 1986. U2 RNA from yeast is unexpectedly large and contains homology to vertebrate U4, U5, and U6 small nuclear RNAs. Cell 47:49-59.

2. Black, D. L., B. Chabot, and J. A. Steitz. 1985 . U2 as well as U1 small nuclear ribonucleoproteins are involved in pre-mRNA splicing. Cell 42:737-750.

3. Black, D. L., and J. A. Steitz. 1986. Pre-mRNA splicing in vitro requires intact U4/U6 small nuclear ribonucleoprotein. Cell 46:697-704.

4. Bringmann, P., B. Appel, J. Rinke, R. Reuter, H. Theissen, and R. Lührmann. 1984. Evidence for the existence of snRNAs U4 and $\mathrm{U} 6$ in a single ribonucleoprotein complex and for their association by inter-molecular base-pairing. EMBO J. 3:13571363.
5. Bringmann, P., R. Renter, J. Rinke, B. Appel, R. Bald, and R. Lührmann. 1983. 5'-Terminal caps of snRNAs are accessible for reaction with 2,2,7-trimethylguanosine-specific antibody in intact snRNPs. J. Biol. Chem. 258:2745-2747.

6. Brody, E., and J. Abelson. 1985. The "spliceosome": a yeast pre-messenger RNA associates with a $40 \mathrm{~S}$ complex in a splicingdependent reaction. Science 228:963-967.

7. Brow, D. A., and C. Guthrie. 1988. Spliceosomal RNA U6 is remarkably conserved from yeast to mammals. Nature (London) 334:213-218.

8. Brow, D. A., and C. Guthrie. 1989. Splicing a spliceosomal RNA. Nature (London) 337:14-15.

9. Chabot B., and J. A. Steitz. 1987. Multiple interactions between the splicing substrate and small nuclear ribonucleoproteins in spliceosomes. Mol. Cell. Biol. 7:281-293.

10. Chang, T. H., M. W. Clark, A. J. Lustig, M. E. Cusick, and J. Abelson. 1988. RNA11 protein is associated with the yeast spliceosome and is localized in the periphery of the cell nucleus. Mol. Cell. Biol. 8:2379-2393.

11. Cheng, S.-C., and J. Abelson. 1987. Spliceosome assembly in yeast. Genes Dev. 1:1014-1027.

12. Choi, Y. D., P. J. Grabowski, P. A. Sharp, and G. Dreyfuss. 1986. Heterogeneous nuclear ribonucleoproteins: role in RNA splicing. Science 231:1534-1539.

13. Church, G. M., and W. Gilbert. 1984. Genomic sequencing. Proc. Natl. Acad. Sci. USA 81:1991-1995.

14. Clark, M. W., and J. Abelson. 1987. The subnuclear localization of tRNA ligase in yeast. J. Cell. Biol. 105:1515-1526.

15. Feinberg, A. P., and B. Vogelstein. 1983. A technique for radiolabeling DNA restriction endonuclease fragments to high specific activity. Anal. Biochem. 132:6-13.

16. Frendewey, D., and W. Keller. 1985. The stepwise assembly of a pre-mRNA splicing complex requires U-snRNPs and specific intron sequences. Cell 42:355-367.

17. Grabowski, P. J., S. R. Seiler, and P. A. Sharp. 1985. A multicomponent complex is involved in the splicing of messenger RNA precursors. Cell 42:345-353.

17a.Guthrie, C., and B. Patterson. 1988. Spliceosomal snRNAs. Annu. Rev. Genet. 22:387-418.

18. Hamilton, R., C. K. Watanabe, and H. A. de Boer. 1987 Compilation and comparison of the sequence context around the AUG start codons in Saccharomyces cerevisiae mRNAs. Nucleic Acids Res. 15:3581-3593.

19. Hartwell, H. L. 1967. Macromolecule synthesis in temperaturesensitive mutants of yeast. J. Bacteriol. 93:1662-1670.

20. Hashimoto, C., and J. A. Steitz. 1984. U4 and U6 RNAs coexist in a single small ribonucleoprotein particle. Nucleic Acids Res. 12:3283-3293.

21. Konarska, M. M., and P. A. Sharp. 1986. Electrophoretic separation of complexes involved in the splicing of precursors to mRNAs. Cell 46:845-855.

22. Konarska, M. M., and P. A. Sharp. 1987. Interactions between small nuclear ribonucleoprotein particles in formation of spliceosomes. Cell 49:763-774.

23. Konarska, M. M., and P. A. Sharp. 1988. Association of U2, U4, U5, and U6 small nuclear ribonucleoproteins in a spliceosome-type complex in absence of precursor RNA. Proc. Natl. Acad. Sci. USA 85:5459-5462.

24. Krainer, A. R., and T. Maniatis. 1985. Multiple factors including the small nuclear ribonucleoproteins $\mathrm{U} 1$ and $\mathrm{U} 2$ are necessary for pre-mRNA splicing in vitro. Cell 42:725-736.

25. Kretzen, L., B. C. Rymond, and M. Rosbash. 1987. S. cerevisiae U1 RNA is large and has limited primary sequence homology to metazoan U1 snRNA. Cell 50:593-602.

26. Last, R. L., J. R. Maddock, and J. L. Woolford, Jr. 1987. Evidence for related functions of the RNA genes of Saccharomyces cerevisiae. Genetics 117:619-631.

27. Lin, R. J., A. J. Lustig, and J. Abelson. 1987. Splicing of yeast nuclear pre-mRNA in vitro requires a functional $40 \mathrm{~S}$ spliceosome and several extrinsic factors. Genes Dev. 1:7-18.

28. Lin, R. J., A. J. Newman, S.-C. Cheng, and J. Abelson. 1985. Yeast mRNA splicing in vitro. J. Biol. Chem. 260:14780-14792.

29. Lossky, M., G. J. Anderson, S. P. Jackson, and J. Beggs. 1987. 
Identification of a yeast snRNP protein and detection of snRNPsnRNP interactions. Cell 51:1019-1026.

30. Lührmann, R. 1988. snRNP proteins, p. 71-99. In M. L. Birnstiel (ed.), Structure and function of major and minor small nuclear ribonucleoprotein particles. Springer-Verlag KG, Berlin.

31. Lustig, A. J., R. J. Lin, and J. Abelson. 1986. The yeast RNA gene products are essential for mRNA splicing in vitro. Cell 47:953-963.

32. Maniatis, T., and R. Reed. 1987. The role of small nuclear ribonucleoprotein particles in pre-mRNA splicing. Nature (London) 325:673-678.

33. Maxam, A. M., and W. Gilbert. 1977. A new method for sequencing DNA. Proc. Natl. Acad. Sci. USA 74:560-564.

34. Mott, J. E., R. A. Grant, Y.-S. Ho, and T. Platt. 1985. Maximizing gene expression from plasmid vectors containing the $\lambda \mathrm{P}_{\mathrm{L}}$ promoter: strategies for overproducing transcription termination factor $\rho$. Proc. Natl. Acad. Sci. USA 82:88-92.

35. Newman, A. J., R. J. Lin, S.-C. Cheng, and J. Abelson. 1985. Molecular consequences of specific intron mutations on yeast mRNA splicing in vivo and in vitro. Cell 42:335-344.

36. Patterson, B., and C. Guthrie. 1987. An essential yeast snRNA with a U5-like domain is required for splicing in vivo. Cell 49:613-624.

37. Phizicky, E., R. C. Schwartz, and J. Abelson. 1986. Saccharomyces cerevisiae tRNA ligase. J. Biol. Chem. 261:2978-2986.

38. Pikielny, C. W., B. C. Rymond, and M. Rosbash. 1986. Electrophoresis of ribonucleoproteins reveals an ordered assembly pathway of yeast splicing complexes. Nature (London) 324: 341-345.

39. Ruby, S. W., and J. Abelson. 1988. An early and hierarchic role of the U1 snRNP in spliceosome assembly. Science 242:10281035.

40. Sanger, F., S. Nicklen, and A. R. Coulson. 1977. DNA sequenc- ing with chain-terminating inhibitors. Proc. Natl. Acad. Sci. USA 74:5463-5467.

41. Sharp, P. A. 1987. Splicing of messenger RNA precursors. Science 235:766-771.

42. Siliciano, P. G., D. A. Brow, H. Roiha, and C. Guthrie. 1987. An essential snRNA from $S$. cerevisiae has properties predicted for U4, including interaction with a U6-like snRNA. Cell 50: 585-592.

43. Siliciano, P. G., M. H. Jones, and C. Guthrie. 1987. S. cerevisiae has a U1-like snRNA with unexpected properties. Science 237:1484-1487.

44. Soltyk, A., M. Tropak, and J. D. Friesen. 1984. Isolation and characterization of the $\mathrm{RNA2}^{+}, \mathrm{RNA4}^{+}$, and $\mathrm{RNAII}^{+}$genes of Saccharomyces cerevisiae. J. Bacteriol. 160:1093-1100.

45. Steitz, J. A., D. Black, V. Gerke, K. A. Parker, A. Kramer, D. Frendewey, and W. Keller. 1988. Functions of the abundant U-snRNPs, p. 115-154. In M. L. Birnstiel (ed.), Structure and function of major and minor small nuclear ribonucleoprotein particles. Springer-Verlag KG, Berlin.

46. Studier, F. W., and B. A. Moffatt. 1986. Use of bacteriophage T7 RNA polymerase to direct selective high-level expression of cloned genes. J. Mol. Biol. 189:113-130.

47. Tabor, S., and C. C. Richardson. 1985. A bacteriophage T7 RNA polymerase/promoter system for controlled exclusive expression of specific genes. Proc. Natl. Acad. Sci. USA 82:1074-1078.

48. Towbin, H., T. Staehelin, and J. Gordon. 1979. Electrophoretic transfer of proteins from polyacrylamide gels to nitrocellulose sheets: procedure and some applications. Proc. Natl. Acad. Sci. USA 79:5188-5189.

49. Zerbib, D., M. Jakowec, P. Prentki, D. J. Galas, and M. Chandler. 1987. Expression of proteins essential for IS1 transposition: specific binding of InsA to the ends of IS1. EMBO J. 6:3163-3169. 